Swarthmore College

Works

10-1-1979

\title{
Agenda Setting And Bargaining Power: The Mexican State Versus Transnational Automobile Corporations
}

D. C. Bennett

Kenneth Evan Sharpe

Swarthmore College, ksharpe1@swarthmore.edu

Follow this and additional works at: https://works.swarthmore.edu/fac-poli-sci

Part of the Political Science Commons

Let us know how access to these works benefits you

\section{Recommended Citation}

D. C. Bennett and Kenneth Evan Sharpe. (1979). "Agenda Setting And Bargaining Power: The Mexican State Versus Transnational Automobile Corporations". World Politics. Volume 32, Issue 1. 57-89. DOI: $10.2307 / 2010082$

https://works.swarthmore.edu/fac-poli-sci/74

This work is brought to you for free by Swarthmore College Libraries' Works. It has been accepted for inclusion in Political Science Faculty Works by an authorized administrator of Works. For more information, please contact myworks@swarthmore.edu. 


\section{AGENDA SETTING AND BARGAINING POWER:}

\section{The Mexican State versus Transnational Automobile Corporations}

By DOUGLAS C. BENNETT and KENNETH E. SHARPE*

\section{INTRODUCTION}

$\mathrm{T}$ this paper, we will explore the often conflictual bargaining rela1 tions between transnational corporations (TNCs) and the host governments of less developed countries (LDCs). Our attention will focus on the issues of agenda setting and the sources of bargaining power in a specific case-the conflict that surrounded the creation of the Mexican automobile industry (1960-1964). ${ }^{1}$

When the administration of Adolfo López Mateos took office in December 1958, there was no significant automobile industry in Mexico. All cars sold in Mexico were either imported whole or as CKD (completely knocked-down) kits that needed only to be assembled. The new government considered the industry to be an important candidate for import substitution, one that-through the manifold forward and backward linkages of auto manufacture-could help to reinvigorate a growth strategy that was showing signs of having exhausted its "easy stage." When the automobile firms that did exist in Mexico showed no inclination to increase the scope of their operations, the government of López Mateos sought to use the state's power to compel the local

* This article was prepared in connection with a research planning activity on the political economy of the Latin American automobile industry sponsored by the Joint Committee on Latin American Studies of the American Council of Learned Societies and the Social Science Research Council. We would like to thank Morris Blachman, Susan Eckstein, Michael Fleet, Louis Goodman, Rhys Jenkins, Richard Kronish, Ken Mericle, David Moore, and Miguel Wionczek for useful critical comments on an earlier draft. Funding from the following foundations made possible the larger research project of which this paper is a part: The Tinker Foundation, the Social Science Research Council, the Carnegie Endowment for International Peace, and the Doherty Foundation.

${ }^{1}$ Much of the data in this paper are drawn from personal interviews with executives of the automobile industry and with government officials (in Nacional Financiera, Banco de México, and the Ministries of Finance and of Industry and Commerce) who were active in the bargaining during period under discussion. The article is concerned only with automobile policy; truck policy, however, raises similar considerations and in some cases was regulated in a similar way. A number of the issues discussed here will be more fully developed in a larger work now in progress.

(C) 1979 by Princeton University Press

World Politics 0043-8871/79/010057-33\$01.65/1

For copying information, see contributor page 
manufacture of a substantial portion of each vehicle. In view of the size of the Mexican automobile market and the prevailing economies of scale in the industry, the government wanted to limit the domestic industry to very few firms. Because of the intense competition for new markets in the international automobile industry, however, the issue of limiting the number of firms-a matter of the structure of the industry-became a particularly controversial one in the bargaining that ensued between the Mexican Government and the major transnational automobile firms. Other proposals put forward by the Mexican Government-among them certain restrictions on the behavior of the firms that would constitute the industry and on the ownership of these firms -also became issues of contention because the firms believed them to be a threat to their global strategies. Other proposals were not so open to dispute, however. The transnational firms mobilized their power to resist the more uncongenial proposals; on some issues, including the key issue of limiting the number of firms, they succeeded.

In what has become the classic formulation, Charles Kindleberger conceptualized the relationships between transnational firms and the governments of the host countries with regard to direct investment as one of bilateral monopoly: one buyer and one seller of a foreign investment project. "In a typical situation, a company earns more abroad than the minimum it would accept and a country's net social benefits from the company's presence are greater than the minimum it would accept . . . with a wide gap between the maximum and minimum demands by the two parties." ${ }^{2}$ Thus viewed, the outside limits of acceptability could be located by means of economic theory but the precise terms of the investment would be a function of the relative bargaining strengths of the two parties. Equilibrium analysis must give way to power analysis; economics to political science.

This balance-of-bargaining-power approach has proved to be a useful conceptualization in studies of relations between TNCs and the governments of their host countries, ${ }^{3}$ but it is marred by certain recurrent

${ }^{2}$ Charles Kindleberger and Bruce Herrick, Economic Development (3d ed., New York: McGraw-Hill I977), 320.

${ }^{3}$ Among recent literature on this subject, see Theodore H. Moran, "Multinational Corporations and Dependency: A Dialogue for Dependentistas and Non-Dependentistas," International Organization, xxxiI (Winter I978), 79-I00; Moran, Multinational Corporations and the Politics of Dependence: Copper in Chile (Princeton: Princeton University Press 1975); Edith T. Penrose, The Large International Firm in Developing Countries: The International Petroleum Industry (London: Allen and Unwin I968); Raymond Vernon, Sovereignty at Bay: The Multinational Spread of U.S. Enterprises (New York: Basic Books I97I), chap. 3; Raymond F. Mikesell, ed., Foreign Investment in the Petroleum and Mineral Industries: Case Studies of Investor-Host Country Relations (Baltimore: Johns Hopkins Press I97I), chap. 2. For one of the few case 
weaknesses that show its kinship with the pluralist approach to power in American political science. We will focus our attention on two key issues in particular:

(I) Studies utilizing the balance-of-bargaining-power framework have tended to take the agenda of bargaining as given. They have concentrated solely on those issues that happen to be topics of conflict and have failed to ask how this agenda was set. Which actors and which interests have been included in the bargaining, and which have been excluded? Why are some issues and not others contested by the parties to the bargaining?

(2) There are weaknesses as well in explaining the outcomes of bargaining encounters. Sometimes there is a failure to distinguish between potential power and actual power, and thus a failure to explore obstacles to the full utilization of potential power. Of equal importance is a tendency to conceptualize potential power as consisting simply in each actor's possession of certain resources. That approach gives little consideration to the relationships or circumstances that may allow a particular attribute to serve as a source of potential power.

\section{Agenda Setting}

Like the behavioral/pluralist approach to the study of power (to which they perhaps owe unwitting allegiance), studies of bargaining conflicts between TNCs and the LDCs' governments have tended to overlook questions of agenda setting. These studies have accorded consideration solely to overt, "visible" conflicts. They have ignored the question of why some issues and not others became subjects of bargaining and conflict. Bachrach and Baratz's discussion of the "other face of power" first called the attention of political scientists to the questions of agenda setting; they were concerned with the utilization of power to prevent some issues from ever forming part of the bargaining agenda. ${ }^{4}$ There are other considerations in agenda setting that are equally important, however. Instead of excluding certain issues from the bargaining agenda, some key actors may be excluded. As a consequence, their particular concerns and interests may not be articulated unless some other actor has reason to put them forward. In cases where the state is involved in a bargaining situation, it may-for reasons that

studies of a manufacturing industry, see Gary Gereffi, "Drug Firms and Dependency in Mexico: The Case of the Steroid Hormone Industry," International Organization, xxxiı (Winter I978), 237-86.

${ }^{4}$ Peter Bachrach and Morton Baratz, "The Two Faces of Power," American Political Science Review, Vol. 56 (December 1962), 947-52. 
have to do with its social foundations-speak only for certain classes. In Mexico, for example, labor and national entrepreneurs both had interests that were deeply affected by the policy toward the automobile industry. Nevertheless, the bargaining over that policy principally involved only the Mexican Government and the major transnational automobile firms that were based in the United States. The voice of labor was completely excluded, and national entrepreneurs played only a minor role. The exclusion of these actors did not necessarily entail the exclusion of their interests, however: in the bargaining, the Mexican state did articulate some of the interests of the bourgeoisie, though the interests of labor went largely unrepresented.

Noting how and why certain actors (and their interests) are excluded from the bargaining provides one kind of insight into the formation of the bargaining agenda, but there is a further important point to be made about agenda setting. In focusing strictly on overt, visible conflicts-and in taking these issues as the given agenda of bargaining -studies using the balance-of-bargaining-power approach have tended to understate the areas of agreement between TNCs and the LDCs' governments. In studies that concentrate solely on points over which there is conflict, the two actors are often presented as if they were antagonists across the board. The bargaining agenda can be more fully and deeply understood if we attend to areas of agreement (over which there is little or no need to bargain) as well as to areas of disagreement. All the interests of the actors included in the bargaining must be explicated in order to locate points of conflict and of convergence among them.

In so proceeding, we regard interests as having an objective (or "real") basis. A careful examination of the goals and circumstances of each actor will reveal its fundamental interests. By contrast, the standard procedure of the pluralist approach to power considers interests to be merely subjective: an actor's interests are whatever it says they are, and no further analysis or explication is sought. ${ }^{5}$ In basic outline, the interests of our two central actors seem straightforward: the automobile TNCs wanted to maximize broad international earnings, while the Mexican Government sought to promote industrial growth. But there were a number of strategies by which each could have pursued its central goal; thus, subjective considerations entered into the formation of these interests as well. The adoption of particular strategies was not

\footnotetext{
${ }^{5}$ For a discussion of the concept of "interest" in analyses of power, and a critique of purely subjective conceptions, see Steven Lukes, Power: A Radical View (London: Macmillan I974).
} 
a matter of purely voluntary choice by the actors; rather, it was shaped by the national and international contexts in which the actors found themselves. An examination of the bases of the interests of these actors will not only allow us to locate the points at which these interests converge and conflict (constituting the bargaining agenda), but also to anticipate how changes in the contexts of action prompt changes of strategy and interest.

THE INTERESTS OF TNCS AND THEIR RELATIONS TO THE INTERNATIONAL

\section{AUTOMOBILE INDUSTRY}

Two of the central characteristics of the international automobile industry in the late I950s and early 1960s were its high (and increasing) concentration and the internationalization of competition among the surviving firms.

In the very earliest years of the automobile industry, literally hundreds of firms were producing cars in the United States, Britain, France, Germany, and other industrialized countries. The assembly line and other scale-of-production economies, however, and the substantial degree of risk in the industry, served to promote steadily increasing concentration. ${ }^{6}$ In the United States, the number of firms producing automobiles dropped from nine to four in the two decades following World War II. In Europe, a similar process of concentration was taking place; each major producing country tended to have one national firm that competed against a number of smaller foreign (usually American) subsidiaries. ${ }^{7}$ The Japanese automobile industry was later in developing, coming to maturity only very late in the I950s; but here, too, four firms accounted for 82 percent of production by $196 \mathrm{I}$; further concentration was actively promoted by the government. By 1973, the worldwide process of concentration had reached the point where two firms (General Motors and Ford) were responsible for over 40 percent of total automobile sales; the eight largest firms produced about 85 percent. $^{8}$

Changes in the shape of competition among the major automobile producers have been both a cause and a consequence of this increasing concentration. Prior to World War II and extending into the r950s, firms sought to take advantage of economies of scale through longer

${ }^{6}$ On the role that risk plays in the automobile industry, see Lawrence J. White, The Automobile Industry Since 1945 (Cambridge: Harvard University Press I97r), 7-9, 44-49.

${ }^{7}$ Rhys Owen Jenkins, Dependent Industrialization in Latin America: The Automotive Industry in Argentina, Chile and Mexico (New York: Praeger I977), 20.

${ }^{8}$ The largest eight, in order, were G.M., Ford, Chrysler, Fiat, Volkswagen, Toyota, Nissan, and Renault. "New Strategies for a World Auto Market," Business Week, November 24, I973, p. 38 . 
production runs in order to lower costs. Subsequently, non-price forms of competition have predominated. In the United States in particular, annual model changes and the need to supply a full range of models have been important factors in increasing concentration. ${ }^{9}$ Until the mid-I950s, furthermore, the major producers enjoyed a well-protected market in their home base and competed internationally only to the extent of exporting assembled vehicles to less developed countries. The American firms, whose home market was not as protected and who had substantial foreign assembly and manufacturing operations (particularly in Europe), constituted a significant exception to this pattern. Since the mid-r95os (i.e., since the return of a buyer's market), however, there has been a substantial interpenetration among the leading producing countries. In Europe, it was facilitated by the E.E.C., while in the United States it manifested itself by the invasion of the market by European and Japanese small cars.

In the developing countries, this internationalization of competition signaled the end of the geographic division of markets among the major producers (the U.S. firms having previously concentrated on Latin America, and the French and British firms on their former colonies, and so forth). The slowdown in growth of the major industrialized markets led first the European firms (spearheaded by Volkswagen) and later the Japanese firms to begin a worldwide export drive. U.S. hegemony in Latin America was threatened, and this area "became a battleground in the competitive struggle within the automobile industry." 10

As it turned out, the new interest of European and Japanese firms in Latin America coincided with the decision of a number of Latin American governments, including Mexico's, to promote domestic manufacturing of automobiles.

THE STATE'S INTERESTS AND THE MEXICAN POLITICAL ECONOMY

The problem of the interests of the state is particularly difficult conceptually, especially in view of the prevailing tendency (following Weber) to identify the state in terms of means rather than of purposes. A full theory of the state is beyond our scope here, but such a theory would need to view the state as having distinct and discernible interests. These interests can not simply be deduced a priori (from the "nature of the capitalist state," for example), but must be explained

${ }^{9}$ White (fn. 6). See also J. A. Menge, "Style Change Costs as a Market Weapon," Quarterly Economic Journal, Vol. 76 (November 1962), 632-47.

${ }^{10}$ Jenkins (fn. 7), 49. 
by the historical manner in which a state comes to rest on particular social class foundations and by the manner in which it institutionalizes solutions to problems in the domestic and international political economy. ${ }^{11}$ What, then, were the outlines of the Mexican state's interests?

By 1958, the policy of import substitution was firmly entrenched in Mexico's strategy of economic growth. It had started with the insulation of its domestic market during the Depression and World War II; following the war, a policy apparatus (import licenses, tariffs) was instituted to maintain the protection of the domestic market. Between I940 and I960, Mexico's G.N.P. increased at an annual rate of 6.3 percent, with the manufacturing sector (at an average annual growth rate of 7.7 percent), setting the pace.

The particular character of Mexico's strategy of import substitution was conditioned by the changing social foundations of the Mexican regime-especially its attitude toward the domestic private sector, labor, and foreign investment. Despite the strains of social radicalism in the Mexican revolution, primary reliance for investments for economic growth had been placed on the private sector. Lacking a national bourgeoisie that could undertake the necessary entrepreneurial activities, the state deliberately created such a class (one which, as it grew, became increasingly capable of influencing governmental policy). ${ }^{12}$ Official policy encouraged private investment in a number of ways: corporate and personal income taxes were kept low; an orthodox monetary policy (desarrollo establizador), adopted in 1954, allowed the government to finance its expenditures in an essentially non-inflationary manner through the use of complex reserve requirements and selective credit controls that applied to the private banking system; the state provided long-term, low-interest loans through state investment banks and made investments in infrastructure and basic industries (steel, petroleum refining); and government policies allowed for the emergence of a skewed pattern of income distribution through which an affluent upper middle class of sufficient size spurred import-substituted consumer-goods industries despite low per capita income. Labor peace was maintained politically through the corporatist organization of the ruling Partido Revolucionario Institucional (PRI), the co-optation of labor leaders, and occasional repression. The resulting low wages and relative docility of urban and rural workers helped to encourage con-

${ }^{11}$ For a fuller elaboration, see Bennett and Sharpe, "The State as Banker and as Entrepreneur: The Last Resort Character of the Mexican State's Economic Interventions, I9r7-r970," Comparative Politics, forthcoming.

${ }^{12}$ For a more detailed discussion, see $i b i d$. 
tinued high rates of investment. ${ }^{13}$ Thus, while the national bourgeoisie was becoming an increasingly important actor whose interests had to be taken into account by the state, labor and its interests were usually excluded; this pattern was to characterize the bargaining in the auto industry in the early ro6os.

The Mexican state served domestic business interests in another important way: the revolutionary heritage had made economic nationalism a hallmark of government policy for more than fifty years. In some sectors-natural resources, banking, insurance, transportation, communications, and so forth-foreign investment was excluded altogether. Such was not the case in manufacturing: import substitution, particularly as it moved into more sophisticated goods (such as automobiles), required the technology, management capabilities, and marketing skills of transnational corporations. Since 1950, however, the official emphasis toward foreign investment in manufacturing has increasingly been on Mexicanization. Foreign investment is required to be associated with a firm the majority of whose capital is Mexican; this policy allows the participation of TNCs in the economy while preserving a role for the national bourgeoisie. ${ }^{14}$

\section{THE MEXICAN STATE AND THE AUTO TRANSNATIONALS: CONVERGENCE}

\section{AND CONFLICT OF INTEREST}

The reliance on private investment, the political control of labor, and the expanding middle class of consumers proved attractive to foreign investment, Mexicanization notwithstanding. After the Second World War, as the policy of import substitution coincided with the expansionary thrust of U.S. transnational corporations, direct foreign investment in manufacturing increased rapidly-from $\$ 32$ million to $\$ 602$ million between 1940 and 1960. In the automobile industry and other manufacturing, there was a particularly strong convergence of interests between the government's economic policy and the corporate strategies of the transnational firms.

The government had encouraged the assembly of vehicles from im-

${ }^{13}$ Details may be found in Roger D. Hansen, The Politics of Mexican Development (Baltimore: Johns Hopkins Press I97I): Susan Eckstein, Poverty of Revolution (Princeton: Princeton University Press I977); William P. Glade, Jr. and Charles Anderson, The Political Economy of Mexico (Madison: University of Wisconsin Press I968).

${ }^{14}$ On Mexican policy toward foreign investment, see Harry K. Wright, Foreign Enterprise in Mexico (Chapel Hill: University of North Carolina Press I97I); and Douglas Bennett, Morris Blachman, and Kenneth Sharpe, "Mexico and Multinational Corporations: An Explanation of State Action," in Joseph Grunwald, ed., Latin America and World Economy: A Changing International Order (Beverly Hills: Sage Publications 1978 ). 
ported CKD kits as early as 1925. Ford took advantage of the modest tariff reductions offered and began assembly in 1926; General Motors followed suit in 1937; and a Mexican firm, Fábricas Auto-Mex, started assembling Chryslers in 1938. When import substitution was adopted as a conscious strategy after World War II, import quotas and additional tariff advantages promoted the creation of a number of other assembly operations. There was little conflict of interest here: shipment of parts in CKD kits still allowed the longer production runs (and lower per-unit costs) in the TNCs' home plants which the stiffened international competition required. In auto manufacture, economies of scale are very much lower in assembly operations than they are in the fabrication of motors or in body stamping. In addition, domestic (Mexican) assembly resulted in some economies in transportation costs. ${ }^{15}$ When the government's policy moved from a concern with assembly toward an interest in the manufacture of vehicles, however, the convergence of interest between the Mexican state and the transnational automobile firms began to disintegrate.

The policy started to change when the López Mateos Administration came to power in December 1958. The growth "miracle" that had been sustained for nearly twenty years was in serious difficulty. The "easy stage" of import substitution was facing exhaustion: Mexico had already initiated the domestic manufacture of many simple consumer goods, and investments were needed in certain industrial sectors if growth was to continue. The attention of economic policy makers focused on a number of candidates, among them the automobile industry.

The Mexican automobile industry in 1958 consisted of eleven firms that were operating assembly plants. In addition, a small number of assembled vehicles were imported by a few other companies. The Mexican consumer could choose from among 44 makes and I 7 models. Ford, General Motors, and Fábricas Auto-Mex dominated the industry; between them, they accounted for three-quarters of the automobiles sold. Ford and G.M. were roo percent foreign-owned subsidiaries; Fábricas Auto-Mex, long wholly owned by the Azcárraga family, sold one-third of its equity to Chrysler in 1959. The other assembly plants were smaller and wholly Mexican-owned; they operated under licenses from foreign manufacturers.

A number of considerations suggested that the automobile industry be a candidate for the implementation of the new policy. Domestic manufacture of automobiles (as opposed to their mere assembly) would

${ }^{15}$ Jenkins (fn. 7), 39-40. 
stimulate a broad array of other industries through backward and forward linkage; it would be expected to further not only an auto-parts industry, but also the sectors that would serve it: machine tools, forgings, paint, glass, steel and aluminum, plastics, and so forth. Automobile manufacturing would thus create a large number of new jobs. There would be savings in foreign exchange: imports of parts and finished vehicles accounted for approximately i I percent of Mexico's total import bill during the I950s; foreign ownership of the major firms (with resultant profit remittances) tended to exacerbate this problem. The fact that Argentina and Brazil had already moved to start up their own automobile manufacture set an example, but also constituted a threat; if Mexico did not follow suit, these countries might pressure Mexico to open its markets to their auto exports under the terms of the Latin American Free Trade Area agreements. ${ }^{16}$

The groundwork was done by the Committee for Planning and Development of the Automobile Industry, an interministerial technical body constituted in I959 and headed by the state's principal development bank, Nacional Financiera (NAFIN). Represented were the Ministry of Finance, the Ministry of Industry and Commerce, and the Bank of Mexico. Final responsibility for formulating and administering the policy rested with the Ministry of Industry and Commerce.

On the basis of considerable staff research and visits to a number of countries (including several that had recently initiated the manufacture of automobiles), but without much consultation with the transnational automobile firms-the bargaining came later-the Committee prepared and approved a report. ${ }^{17}$ It constituted the initial policy position of the government's economic técnicos.

Because there were a number of these proposals, we will divide them into three types: proposals concerning the structure of the industry, proposals concerning the behavior or conduct of the firms, and proposals concerning the ownership of the firms. ${ }^{18}$

${ }^{16}$ See the statement of López Mateos's Minister of Industry and Commerce, Raúl Salinas Lozano, in Comercio Exterior, August 1964, pp. 547-48; and Salinas Lozano's introduction to Héctor Vázquez Tercero, Una década de política sobre la industria automotriz (Mexico, D.F.: Editorial Tecnos 1975), 5-10.

In interviews, a number of officials of the Ministry of Commerce maintained that the balance of payments was not a primary concern (since domestic manufacture would create its own imports for machinery and raw materials). In their view, industrial growth and employment were the principal concerns.

${ }_{17}$ Nacional Financiera, Elementos para una política de desarrollo de la fabricación de vehículos automotrices en México (Mexico, D.F.: Nacional Financiera 1960).

${ }^{18}$ The concepts of industry structure and firm behavior are drawn from industrial organization theory: see Joe S. Bain, Industrial Organization (New York: Wiley 1959). The presumption underlying the theory is that structure affects firm behavior, and 
A. PROPOSALS CONCERNING THE INDUSTRY'S STRUCTURE

I. Limitation of the number of firms in the terminal industry (production of finished vehicles) to three to five firms

2. Limitation of the terminal firms to motor machining and final assembly (other manufacturing to be reserved for a supplier or auto-parts industry)

3. Creation of a central body-stamping plant.

B. PROPOSALS CONCERNING THE FIRMIS' BEHAVIOR

I. Production of at least 60 percent of the content of vehicles (measured by direct cost) in Mexico

2. Limitations on the number of acceptable makes and models produced by each firm

3. Limitations on frequency of model changes (freezing of model years)

4. Standardization of certain parts.

C. PROPOSALS CONCERNING THE OWNERSHIP OF FIRMS

I. Mexican majority ownership of firms in the terminal industry

2. Mexican majority ownership of firms in the supplier industry.

These proposals followed from the government's conception of what was required to sustain economic growth, but the transnational automobile firms saw a number of the proposals as threatening their corporate strategies. The bargaining that followed the emergence of this conflict of interests unfolded in two stages. The first stage encompassed the various discussions between the firms and the Ministry of Industry and Commerce prior to the promulgation of the Manufacturing Decree of August 1962, and concerned the terms of the Decree; the second stage consisted in the submission and approval of applications by various firms to manufacture under the terms of the Decree. Issues of ownership and firm behavior were contested in the first stage. Ford, General Motors, and Fábricas Auto-Mex were the major actors: they were the only transnational auto firms who had already invested substantial capital in Mexico; together, they dominated the Mexican market. The number of firms to be admitted-the principal issue of industry structure-was discussed in both stages; consequently, all firms applying for entry (whether U.S.-based or not) participated in the negotiations.

behavior in turn leads to performance (the type of contribution that an industry makes to the functioning of an economy) that can be judged against certain standards. I.O. theory, like economic theory more generally, considers ownership to be irrelevant, assuming a rational actor to be directing the firm. A different presumption has underlain the policies of the Mexican Government (among others) toward direct foreign investment: that the nationality of the ownership does make a difference in the firm's behavior, and thus in performance. 
The bargaining involved four closely related issues.

(I) The requirement of 60 percent local content. The government's interest here was clear: this requirement was to move the Mexican auto industry from assembly to manufacture, and thus to stimulate further import substitution.

The TNCs, however, were not eager to commence manufacturing operations on this basis. The new investments would be far greater than those already in assembly plants. (The TNCs who merely licensed Mexican-owned assembly operations had yet to commit any capital investment to Mexico.) The Mexican market was still quite small-only 65,000 autos and trucks in I962; manufacturing in Mexico would mean the surrender of important economies of scale. Finally, there were serious difficulties of supply, since the existing auto-parts industry had been limited mainly to the manufacture of simple replacement parts. The creation of an adequate parts industry would be a substantial undertaking, involving considerations of quality and availability as well as of cost. In some cases, the necessary raw materials were not available at acceptable prices or levels of quality.

Surprisingly, however, the TNCs did not take a position in bargaining that was totally set against auto manufacturing in Mexico; the explanation lies in the emergent dynamics of internationalized competition among the firms in the world automobile oligopoly. As Knickerbocker has shown, direct foreign investment in competitive, product-pioneering, manufacturing oligopolies tends to conform to a follow-the-leader pattern of defensive investment. "Rival firms in an industry composed of a few large firms counter one another's moves by making similar moves themselves" as a risk-minimizing strategy. ${ }^{19}$ When one firm in the oligopoly makes an investment, other firms defend their positions by making similar investments. In the present case, the Mexican Government (rather than an independent investment decision by one of the firms) triggered the process; as soon as one of the firms agreed (early in the policy-making process, Ford had expressed a willingness to commence manufacturing under the right conditions), the other firms were quick to follow. Eighteen firms submitted applications when the final Decree stipulating automobile manufacturing was promulgated in August 1962. ${ }^{20}$ Thus, although it may not have

${ }^{19}$ Frederick T. Knickerbocker, Oligopolistic Reaction and Multinational Enterprise (Boston: Harvard University School of Business Administration 1973), I. Cf. Jenkins (fn. 7), 40-42. For a discussion of oligopolistic reaction in another industry in Mexico, see Gary Gereffi (fn. 3), 27I-72.

${ }^{20}$ The same pattern of oligopolistic reaction is to be seen all over Latin America. When Brazil imposed its manufacturing requirements in 1956, i I firms commenced 
been in the interests of the individual firms to commence manufacturing operations in Mexico, they were prepared to do so rather than risk the possibility of that market's being conceded to a competitor.

Consequently, the requirement that, on average, 60 percent of each vehicle be manufactured in Mexico never became an issue of contention in the bargaining between the Mexican state and the transnational automobile firms. ${ }^{21}$

(2) Limiting the number of firms-the central issue of the industry's structure. Strictly limiting the number of firms to no more than five was a key provision of the Nacional Financiera Report; it became the most important one in the bargaining. This proposal constituted the Mexican Government's attempt to learn from the mistakes of unrestricted entry of automobile manufacturers in Brazil and Argentina (eleven and twenty-one, respectively). The Mexican market was not expected to exceed a few hundred thousand vehicles annually within the next decade. Allowing the market to become fragmented among many firms, each with a multiplicity of makes and models, would result in overcapitalization and excess capacity in the industry, and would lead to higher consumer prices and thus lower demand. The industry could achieve the significant economies of scale available in automobile manufacture only if the number of firms could be limited. ${ }^{22}$

manufacturing operations; when Argentina announced its policy in 1959, 22 firms made the necessary investments; in Chile, 20; in Venezuela, I6; in Peru, I3. Jenkins (fn. 7), 56 .

21 It is worth mentioning that this requirement was made palatable by being considerably lower than the mandatory levels of local content that had been required by Brazil and Argentina a few years earlier, as well as certain attractive tax exemptions. On the latter, see Jenkins (fn. 7), 54-55. Jenkins takes pains to argue, however, that these tax incentives themselves were not responsible for the large number of firms that were willing to commence manufacturing. With regard to the 60 percent of local content, it was the intention of the Mexican policy makers to start at this lower level in order to minimize the inflationary consequences of the transition to domestic manufacture (a low level of inflation being an important goal of the government's policy). With the industry's growth in size and efficiency, a gradual increase to higher levels was expected.

${ }^{22}$ On these economies of scale, see White (fn. 6), 38-53, and Jenkins (fn. 7), 265-7r. Even such otherwise staunch defenders of free trade as I.M.D. Little, Tibor Scitovsky, and Maurice Scott advocate the use of investment controls by developing countries in order to limit the number of firms in an industry with significant economies of scale; they single out the automobile industry as an example. Industry and Trade in Some Developing Countries: A Comparative Study (London: Oxford University Press 1970), 342 .

Another proposal put forward in the Nacional Financiera Report-the establishment of a single, central body-stamping plant-was aimed at the same goal. The plant, to be developed by Altos Hornos, the state's steel firm, would make it possible for all the manufacturers to use the same body stamping presses, with only the stamping dies needing to be changed for each firm. If models were extended for several years each, these dies could be used to nearly full efficiency. 
In view of the gains in efficiency, none of the automobile producers opposed such a limitation on the number of firms in principle, though perhaps the American manufacturers were made uncomfortable by a governmental stipulation of this sort. What worried each of them was the prospect that it might be one of the excluded ones-a prospect that was of particular concern to the American firms which already had a major stake in the Mexican market. If the Mexican Government were to provide a place for its state-owned auto firm (Diesel Nacional), favor producers of small cars, attempt to diversify the country's sources of foreign investment, and give preference to Mexican-owned firmsall measures that the government had indicated it was inclined to pursue-then a limitation on the number of firms would surely spell exclusion for one or more of the American producers. Consequently, the issue of exclusion became a highly disputed one in the bargaining. In the first stage of the negotiations, the American firms lobbied in order to remove from the Decree any specific limit on the number of firms that would be permitted. In the second stage, a large number of firms took steps to insure that they would not be excluded.

(3) The issues of firm behavior. Like the proposed limitation on the number of firms, various measures-standardization of parts, freezing of models, limitations on acceptable makes and models-were proposed in the Nacional Financiera Report to insure greater efficiency. Each of them would increase the volume of each part or unit manufactured, and thus allow greater economies of scale. These issues became controversial in the first stage of the bargaining because they threatened the dominant competitive strategies of the U.S. firms. By contrast with European and Japanese companies (whose competition was just becoming a threat to them at home and in Latin America), the U.S. firms favored a strategy of product differentiation based on annual model changes. They also stressed the differences in performance characteristics of their motors; the latter were leading candidates for standardization.

(4) The issue of ownership. The proposal by the Nacional Financiera Report that all of the firms be more than 50 percent Mexican-owned reflected the longstanding nationalist orientation of the Mexican state and its desire to encourage and protect Mexican private investment. Furthermore, participation of Mexican investors might help to ensure that the interests of the TNC's subsidiary in Mexico would not be sacrificed to the global rationality of the parent company when the two were in conflict. ${ }^{23}$ This issue, too, was negotiated in the first stage

${ }^{23}$ On the sometimes dubious logic of equity participation as a means to control TNC 
and came into sharp contention because it threatened a basic operating procedure of two of the American firms-one hundred percent ownership of foreign subsidiaries. Ford and General Motors had adopted a worldwide policy of not entering into joint ventures with foreign nationals; an exception in Mexico might lead to a similar insistence on joint-venture status by other developing countries.

Although technically an issue of industry structure, the proposed restrictions on vertical integration of the terminal firms (limiting them to assembly operations, machining of engine blocks, and any manufacturing operations in which they had been engaged prior to the Decree) were also aimed partly at ownership. Such restrictions would reserve a place for the national bourgeoisie in the manufacture of auto parts, ${ }^{2+}$ particularly important if the American TNCs prevailed on the issue of ownership. The transnational firms opposed this limitation as well, though with much less vehemence. It would make them dependent on the quality, price, and availability of Mexican-made parts, but it did not threaten their entrenched worldwide competitive strategies. The proposed requirement would limit them to approximately the same array of activities in which they were engaged in the United States (where, because of risk-sharing considerations, a large number of parts are supplied by independent manufacturers).

The interests of the TNCs and the Mexican state conflicted most sharply over the proposals that concerned limiting the number of firms, certain issues of firm behavior (standardization of parts, freezing of models), and ownership restrictions. Consequently, these issues formed the major items on the bargaining agenda. Answering the questions of who prevailed, and why, requires attention to the bases of potential power and to the factors that influence an actor's ability to utilize its potential power fully in a particular contest. We will focus our attention on the issue of limiting the number of firms. Not only was this the point on which the interests of the actors diverged most sharply; it was also the one that would most seriously affect the course of the industry and the success of future governmental regulatory policy.

behavior, see Bennett and Sharpe, "Controlling the Multinationals: The Ill Logic of Mexicanization," in Lawrence V. Gould, Jr. and Harry Targ, eds., Global Dominance and Dependence: Readings in Theory and Research (Brunswick, Ohio: King's Court Communications, forthcoming).

${ }^{24}$ Restrictions on vertical integration would have two other effects as well: they would encourage economies of scale by avoiding the duplication of parts manufactured in each separate terminal firm, and they would allow better regulation of the requirement of 60 percent local content by making it more difficult for the terminal industry to manipulate percentages through transfer pricing. 


\section{Bargaining Power}

When the Automobile Manufacturing Decree was promulgated in August 1962, it was evident that the bargaining of the U.S. transnationals had succeeded in changing considerably the proposals that had first been put forward in the Nacional Financiera Report. ${ }^{25}$ While automobile firms producing for the Mexican market would be required to incorporate at least 60 percent of locally manufactured content in each of their vehicles, and limits were placed on the vertical integration of the firms, the Decree required nothing in the way of Mexicanization of the terminal firms. The other proposals regarding firm behavior had been dropped. Most importantly, the Decree set no explicit limit on the number of firms that would be allowed to operate in Mexico: Io of the I8 firms that had applied were approved. (See Table.)

What had transpired in the bargaining? What was the relative power of the actors? How and why did they exercise (or not exercise) the potential power at their disposal?

\section{SOURCES OF POTENTIAL POWER}

The relative power of actors ought not to be gauged merely from the outcome of a conflict. Such a post hoc analysis of power tends to exclude any meaningful analysis of why a particular outcome occurred, and forecloses the possibility that one actor had potential power it did not exercise. ${ }^{26}$ In the pluralist approach, potential power is generally conceptualized as consisting in the actors' possession of certain resources. The following passage from a distinguished work in the balance-of-bargaining-power literature illustrates the approach:

The foreign investor offers capital, know-how (technological and managerial), some opportunities of commercialization, and, among other possibilities, that of a certain structure of industrial development. The host country offers access to the home market (particularly in the manufacturing sector), access to natural resources (as in extractive industries), and access to special comparative advantages (such as cheap labour). ${ }^{27}$

Variations in these resources may well explain differences in bargaining power. In the Mexican case, the automobile companies had capital,

${ }^{25}$ For the full text of the Decree, see Diario Oficial de la Federación, August 25, 1962.

${ }^{26}$ For a recent employment of these concepts of potential and actual power in a general approach to international relations, see Robert O. Keohane and Joseph S. Nye, Power and Interdependence: World Politics in Transition (Boston: Little, Brown I977), II, 53, and passim.

${ }_{27}$ Constantine V. Vaitsos, Intercounty Income Distribution and Transnational Enterprises (Oxford: Clarendon Press 1974), II9. 
Firms Admitted under the 1962 Automobile Manufacturing Decree

\begin{tabular}{|c|c|c|c|}
\hline $\begin{array}{c}\text { Name of Firm and Date } \\
\text { of First Approval }\end{array}$ & Make & $\begin{array}{c}\text { Ownership at Time of } \\
\text { First Approval }\end{array}$ & Subsequent Changes in Status \\
\hline $\begin{array}{l}\text { DIESEL NACIONAL } \\
\text { (December 1962) }\end{array}$ & Renault & $\begin{array}{l}100 \% \text { domestic } \\
\quad(\text { Mexican State) }\end{array}$ & 1978: $40 \%$ equity sold to Renault \\
\hline $\begin{array}{l}\text { FÁBRICAS AUTO-MEX } \\
\text { (December 1962) }\end{array}$ & Chrysler & $\begin{array}{l}33 \% \text { foreign } \\
67 \% \text { domestic }\end{array}$ & $\begin{array}{l}\text { 1970-1971: Chrysler increased } \\
\text { its holdings to } 99 \% \text {; name } \\
\text { changed to CHRYSLER DE } \\
\text { MÉXICO }\end{array}$ \\
\hline $\begin{array}{l}\text { FORD MOTOR CO. } \\
\text { (December 1962) }\end{array}$ & Ford & $100 \%$ foreign & None \\
\hline $\begin{array}{l}\text { GENERAL MOTORS DE } \\
\text { MÉXICO } \\
\text { (December 1962) }\end{array}$ & General Motors & $100 \%$ foreign & None \\
\hline $\begin{array}{l}\text { PROMEXA } \\
\text { (December 1962) }\end{array}$ & Volkswagen & $100 \%$ domestic & $\begin{array}{l}\text { 1963: } 100 \% \text { equity sold to } \\
\text { Volkswagen A.G.; name } \\
\text { changed to VOLKSWAGEN DE } \\
\text { MÉXICO }\end{array}$ \\
\hline $\begin{array}{l}\text { VEHÍCULOS AUTOMO- } \\
\text { TORES MEXICANOS } \\
\text { (December 1962) }\end{array}$ & $\begin{array}{c}\text { American } \\
\text { Motors }\end{array}$ & $100 \%$ domestic & $\begin{array}{l}\text { 1963: } 40 \% \text { equity sold to American } \\
\text { Motors; remaining } 60 \% \text { acquired by } \\
\text { Mexican state (SOMEX) }\end{array}$ \\
\hline $\begin{array}{l}\text { IMPULSORA MEXICANA } \\
\text { AUTOMOTRIZ } \\
\text { (January 1963) }\end{array}$ & Borgward & $100 \%$ domestic & $\begin{array}{l}\text { 1963: name changed to } \\
\text { FÁBRICA NACIONAL DE } \\
\text { AUTOMOVILES } \\
\text { 1969: ceased operations }\end{array}$ \\
\hline $\begin{array}{l}\text { REO DE MÉXICO } \\
\text { (January 1963) }\end{array}$ & Toyota & $100 \%$ domestic & 1963: ceased operations \\
\hline $\begin{array}{l}\text { REPRESENTACIONES } \\
\text { DELTA } \\
\text { (Mid-1963) }\end{array}$ & D.K.W. & $100 \%$ domestic & 1964: ceased operations \\
\hline $\begin{array}{l}\text { NISSAN MEXICANA } \\
\text { (Late 1964) }\end{array}$ & Datsun & $100 \%$ foreign & None \\
\hline
\end{tabular}


technology, and administrative and marketing know-how; the government controlled access to the domestic market, and could (through tax policy, its control of the labor force, and so forth) influence the price of various factors of production. An additional resource that strengthened the hand of the government was its increasing technical expertise, which had been gained by careful study of automobile manufacturing in other countries. ${ }^{28}$

It is not an adequate approach, however, to conceive of potential power simply in terms of the possession of certain resources. What is needed as well is an understanding of how an actor's potential power is shaped by the complex web of relationships-relationships with actors not directly party to the bargaining-in which each actor is enmeshed. ${ }^{29}$ The relationships in which we are interested in the present case are conceptualized somewhat differently in world system theory, ${ }^{30}$ in dependency theory, ${ }^{31}$ and in models of the international power structure and of international organization ${ }^{32}$ - to mention a few of the more prominent contemporary analyses. There are important issues separating these approaches, particularly with regard to how asymmetries in global relationships are conceptualized and made subject to empirical analysis. For the purposes of the present investigation, we intend to avoid entering the lists on behalf of any one approach by limiting our attention to the particular set of international and transnational relationships that bear on the case at hand. Most of them have been introduced in Part II (Agenda Setting). We will be especially interested in the relationships among the transnational corporations in the international automobile industry, the relationships of these transnational firms to domestic firms in Mexico, the relationships between the Mexican state and the home governments of the TNCs, the relationships

${ }^{28}$ It is important to note that this resource was different in kind from the other resources since it could not (as the other resources could) be used or withheld as a sanction. It was an infra-resource rather than an instrumental resource; it allowed other resources to be utilized to better advantage. On the notion of infra-resources, see Mary F. Rogers, "Instrumental and Infra-Resources: The Bases of Power," American Journal of Sociology, Vol. 79 (May 1974), I4I8-33.

${ }^{29}$ This myopia arises partly from the strictly dyadic character of the standard pluralist conception of power (" $A$ has power over $B$," etc.). Such an approach abstracts the actors from all other significant relationships in which they are engaged, and thus seeks to locate potential power apart from these other significant relationships.

${ }^{30}$ Immanuel Wallerstein, The Modern World System (New York: Academic Press 1974).

${ }^{31}$ See, among others, Theotonio dos Santos, "The Structure of Dependence," American Economic Review, Vol. 6o (May 1970), 231-36; Fernando Henrique Cardoso and Enzo Faletto, Dependency and Development in Latin America (Berkeley: University of California Press 1979).

${ }^{32}$ On these, see Keohane and Nye (fn. 26), 42-49 and 54-58. 
between the Mexican state and certain domestic social classes-especially the bourgeoisie, and the relationships among various ministries and agencies of the Mexican state.

We will argue that the structure of these particular relationships (I) defines what constitutes a power resource, (2) determines when such resources can be employed or withheld, and (3) determines the potential for the entry of new actors into the conflict as allies or as antagonists.

(I) The structure of relationships defines what constitutes a power resource. One danger of regarding potential power as consisting simply of the possession of certain resources is the tendency to an easy but dangerously misleading supposition that power resources are "fungible"-that the possession of power resources gives one a generalized capacity which can be employed whenever and wherever one pleases. ${ }^{33}$ Power resources are not entirely interchangeable from context to context, or from contest to contest. What serves as a basis of power in one situation may be worthless, perhaps even a liability, in another. This lack of fungibility of power resources is commonly paid due obeisance: what constitutes a power resource depends on the context-on who is trying to get whom to do what; the scope and domain must be specified. ${ }^{34}$ Quite obviously, the TNCs' control over automotive technology gave them potential power only in a context where it was desired that automotive products be domestically manufactured. But it is not suffcient (though power discussions rarely go further) merely to stipulate the context-dependency of power resources. Rather than delimiting the appropriate context by fiat, we need an analysis that shows how and why certain resources come to serve as bases of power in particular circumstances. Such an analysis will have to feature the specification of relationships of dependency and interdependency in which the

${ }^{33}$ The phrase is from Talcott Parsons, whose suggestion that power be seen on the analogy of money leads to the erroneous supposition of the fungibility of power. See Parsons, "On the Concept of Political Power," in Sociological Theory and Modern Society (New York: Free Press 1967). For a corrective, see David Baldwin, "Money and Power," Journal of Politics, xxxiri (August r97r), 578-6r4.

${ }^{34}$ Thus, for example, Robert Dahl: "The domain of an actor's influence consists of the other actors influenced by him. The scope of an actor's influence refers to the matters on which he can influence them. . . . Any statement about influence that does not clearly indicate the domain and scope it refers to verges on being meaningless." Dahl, Modern Political Analysis (3d ed.; Englewood Cliffs, N.J.: Prentice-Hall I976), 33 .

For a recent and thorough review of the power literature that pays particular attention to the questions of the fungibility and context dependency of power resources, see David Baldwin, "Power Analysis and World Politics: New Trends versus Old Tendencies," World Politics, xxxi (January I979), I6I-94. 
actors are enmeshed, and which serve to constitute certain resources as bases of power.

To return to our example, if we say that Mexico's need for automotive technology is what made the TNCs' possession of such technology a basis of power, we need to ask the further question how and why Mexico's need arose; we must not take it for granted. Over several decades, the Mexican state had committed itself to rapid economic growth; its continuation had become a central basis of the regime's legitimacy. Once industrialization of import substitution had been adopted as the growth strategy, it had requisites of its own. When the strategy was threatened with exhaustion in the late I950s, the state decreed that the automobile sector should commence domestic manufacture. These are important features of the context, but they do not explain why the transnational corporations were needed for technology (and investments). A functional, if not stylish, car of Mexican design was probably not beyond the bounds of feasibility. ${ }^{35}$ In order to understand Mexico's need for the TNCs, it is necessary to be aware of the nature of the class structure that had evolved under import substitution, and particularly of the relationship between the Mexican state and the national bourgeoisie. This bourgeoisie had been nurtured for thirty years to pace economic growth; its increasing size and power and its centrality to the growth project made it one of the prime social foundations of the state. Import substitution had been impelled by the burgeoning consumer demand of this national bourgeoisie and of the middle classes (professionals, managers, petite bourgeoisie, and so forth) that had been spawned with it. However, these classes wanted what they had become accustomed to: modern, U.S.-style products. A Mexican car would not have been acceptable. The relationship of the Mexican state to its national bourgeoisie thus demanded that Mexico needed the sort of automobile industry that only the transnational firms could provide.

If the context established Mexico's "need" for the technology of the automobile TNCs, we may then ask how easily the Mexican state could have changed those features of the context that defined the need and thus constituted the technology as a power resource. Clearly, not very easily: fundamental changes in the strategy of economic growth and in the domestic class structure would have been required. ${ }^{36}$

${ }^{35}$ It is noteworthy that the state-owned Diesel Nacional S.A. had already begun work on a medium truck of its own design. Some of its components were imported, some were manufactured under license, and a Detroit engineering firm had been consulted; but it was nonetheless a Mexican truck and proved to be a successful venture.

${ }^{36}$ In Keohane and Nye's terminology, Mexico was both "sensitive" and "vulnerable" 
(2) The structure of relationships determines when power resources can be employed or withheld. Relationships of dependence and interdependence in which the actors are enmeshed affect the choice of their possessions and attributes that may serve as power resources in a particular conflict, but other relationships may serve to limit the actors' freedom to commit or to withhold their resources at will. The structure of relationships defining Mexico's place in the global political economy and the Mexican state's relationship to its domestic class structure decreed the need for a certain kind of automobile industry; the resources of the transnational automobile firms thus became sources of potential power. On the other hand, the pattern of competitive relationships among these transnational automobile firms (in their worldwide competition) served to constrain them from deploying these resources to their own best advantages in bargaining with the Mexican state. More precisely, the follow-the-leader pattern of defensive investment that made the firms so eager to produce for the Mexican market weakened their potential to withhold their participation if conditions and terms were not precisely to their liking. Knickerbocker has called the TNCs' proclivity to defensive investment a "trump card for the LCD": "When one member of the club makes a move, the others pant to follow; and by realizing this, the LDC is in a position to demand a high entrance fee." ${ }^{, 7}$ Since the move to auto manufacture in Mexico coincided with heightened international competition, the potential power of the Mexican state was enhanced as the ability of the TNCs to withhold their resources was weakened. Had the industry been differently organized-had it, for example been characterized by collusion and strategies of mutual forebearance, the Mexican Government would not have had such substantial potential power.

In view of the pattern of competition in the international automobile industry, the Mexican state's control over access to the Mexican market was the most potent power resource available to it in the bargaining, but certain relationships constrained its ability to play this "trump card" to its fullest advantage. Most importantly, in its pursuit of industrial development by way of import substitution, Mexico had come to be dependent upon certain industrialized countries, particularly the United States, for trade and capital inflows. These relationships shaped

to this power resource of the TNCs. "Sensitivity involves degrees of responsiveness within a policy framework" or context, and vulnerability refers to the "relative availability and costliness of the alternatives the various actors face." Keohane and Nye (fn. 26), I2-I3.

${ }^{37}$ Knickerbocker (fn. I9), 197, 198. 
a set of needs for continued flows of trade and capital in a number of sectors that limited the state's power in the automobile sector: a favorable investment climate had to be maintained if growth was to continue. The Mexican Government was forcefully reminded of this limitation just when the automobile policy was first being formulated. In 1960-196r, relations with the United States took a turn for the worse with Mexico's refusal to submit to U.S. pressure to support the trade sanctions against the Castro regime. The U.S. Government and press criticized the "left-wing" tendencies of the López Mateos government -a perception that was reinforced by a variety of new policies toward foreign investment. Since taking office, the López Mateos Administration had nationalized the electric power industry and implemented important new policies in the petrochemical and mining sectors, which were branded as socialist by certain transnational corporations and conservative Mexican business interests. The effect was felt in a flight of capital of about $\$ 200$ million between 1960 and 196 I. $^{38}$ The Mexican Government thus had to be cautious in its treatment of the foreign (especially U.S.) automobile corporations, lest its policy in this sector threaten the wider growth strategy.

The Mexican state's relationship with its own national bourgeoisie also limited its ability to play this trump card of market access to fullest advantage. If some wholly foreign-owned firms were to be approved, it would have been politically disadvantageous not to show a measure of favoritism to some domestically-owned firms that were also requesting approval.

(3) The structure of relationships determines the potential for the entry of new actors into the conflict as allies or as antagonists. Having already established themselves in the Mexican market through their assembly operations, the three major U.S.-based firms (Ford, General Motors and Fábricas Auto-Mex) could draw on support from their consumers and employees, but more importantly from their distributors and from the suppliers of replacement parts and what few parts were procured in Mexico for original equipment. In bargaining, these major U.S. firms could (and did) call attention to the disruption that would attend their exclusion: replacement parts and service would become hard to find; the value of existing vehicles would decline; their distributors would be put out of business; and their Mexican employees would be out of work. The distributors and parts-supply firms made separate representations of these same points, but they were weak and

${ }^{38}$ Miguel Wionczek, El Nacionalismo y la Invérsion Extranjera (Mexico, D.F.: Siglo XXI Editores I967), 240-4I. 
disorganized. It was also impossible to muster a wider alliance between the transnational firms and the national bourgeoisie-for example depicting the attempt to exclude certain TNCs from the market as a general attack on private investment. This strategy had been effective in other cases of LDC-TNC bargaining, ${ }^{39}$ but the Mexican state's clear intention to accord its national bourgeoisie special treatment in the automobile industry through the proposals for Mexicanization and for reservation of the supplier industry forestalled such an alliance.

A more formidable set of allies on which the TNCs drew were their home governments. This article is not the place in which to explore the relationships between the transnational automobile firms and their home governments. ${ }^{40}$ However, the resources of the latter should no more be taken as given than those of the other central actors in the bargaining. They resided precisely in the ability to influence the trade and capital flows between Mexico and the industrialized countries on which Mexico had become dependent. In order to understand the potential power of these home governments we must, therefore, return to our first two points: the interdependent relationships in which Mexico was enmeshed defined the need for resources over which the home governments had a measure of control, and which thus constituted bases of potential power; and the asymmetric character of these trade and investment (inter-)dependencies meant that the home governments were likely to be more free to commit or withhold those resources than the Mexican Government was to choose whether to do without them.

\section{FROM POTENTIAL POWER TO ACTUAL POWER}

How did the two major actors-the TNCs and the Mexican Government-transform (or fail to transform) their potential power into actual power? As Keohane and Nye point out, "political bargaining is the usual means of translating potential into effects, and a lot is often

${ }^{39}$ For such an alliance in the bargaining over copper concessions in Chile, see Moran, Multinational Corporations and the Politics of Dependence: Copper in Chile (fn. 3), 190-97; for such an alliance in Venezuela in the bargaining over oil concessions, see Franklin Tugwell, The Politics of Oil in Venezuela (Stanford: Stanford University Press 1975). For a general discussion of the conditions under which such alliance between TNCs and the national bourgeoisie may form, see Moran in International Organization (fn. 3), 93-95.

${ }^{40}$ For one discussion of these relationships that especially concerns European automobile firms, see Louis T. Wells, "Automobiles," in Raymond Vernon, ed., Big Business and the State (Cambridge: Harvard University Press 1974). For a discussion that illuminates certain aspects of the relationship of the U.S. and Japanese Governments toward their automobile industries, see William Chandler Duncan, U.S.-Japan Automobile Diplomacy (Cambridge: Ballinger Publishing Co. 1973). 
lost in translation." ${ }^{41}$ Our concern will remain focused on the central issue of industry structure: How did the firms prevail over the Mexican Government's efforts to limit the number of enterprises in the industry?

The mobilization of corporate power. The U.S. firms began early to mobilize their power to influence the terms of the Decree. As the NAFIN committee was preparing its report, Ford was already working on a detailed, two-volume proposal of its own. In frequent discussions with officials of the Ministry of Industry and Commerce (SIC), the firms attempted to use their superior know-how to convince Mexican policy planners of the unreasonableness or impracticality of their proposals. However, on the issues of exclusion and ownership (mandatory Mexicanization would have been tantamount to exclusion of Ford and General Motors), and even on certain questions of the firms' behavior, the government técnicos were unmoved. ${ }^{42}$ Distributors and parts suppliers also provided little leverage. Instead, a major key to the success of the TNCs was the support they could mobilize from the U.S. Government.

The Minister of Industry and Commerce was informed by the United States Ambassador that the Department of State would look unfavorably on the exclusion of the U.S. firms. Other high officials of the Ministry were told that any such exclusion would be viewed as a "not very friendly act." ${ }^{43}$ Precisely what was said, however, is not as important as how anything said on this issue by the U.S. Government would be understood. Its explicit backing of the interests of these transnational firms meant that automobile policy would be linked with, and would affect, what happened in other spheres of the bilateral relationship, and that sanctions might be employed beyond those strictly under the control of the three firms. ${ }^{44}$ In view of the strained relations over Cuba and the recent capital flight, the President, Ministers and other officials of the Mexican Government had to be particularly sensitive to the pronouncements of high corporate executives and U.S. Government officials.

${ }^{41}$ Keohane and Nye (fn. 26), I I. Cf. Moran, Multinational Corporations and the Politics of Dependence (fn. 3), I69-2I5.

${ }^{42}$ It does seem, however, that they did not fully appreciate how much the pattern of oligopolistic competition strengthened their hand, nor how zealously the firms would press their cases in their eagerness to be included.

${ }^{43}$ A well-publicized visit by U.S. Ambassador Thomas Mann to the plant of Fábricas Auto-Mex in August 196I made it clear that the United States was interested in the treatment of this firm (which was majority Mexican-owned), as well as of Ford and G.M.'s wholly U.S.-owned subsidiaries.

${ }^{44}$ Another case of U.S. Government intervention on behalf of Ford, G.M., and Chrysler over somewhat similar issues is documented in Duncan (fn. 40). 
Pressure may also have been forthcoming from the West German Government to ensure that at least one German manufacturer was approved. In any case, the desire of the Ministry of Industry and Commerce to include at least one manufacturer of a small inexpensive car (auto popular), their unwillingness to rely wholly on the state-owned Diesel Nacional (Renault) for this purpose, and the Mexican ownership of Promexa (Volkswagen) at the time of approval were probably sufficient to assure the acceptance of Volkswagen as a licensee. (The Mexicans sold out to the German parent company a few months later.)

The acceptance of Nissan's application two years after the legal deadline for approval, however, can only be explained by looking at another relationship between a TNC and its home government. ${ }^{45}$ The Japanese Government utilized an additional and unlikely power resource to gain approval for Nissan: cotton.

In 1963 , cotton was the single most important source of foreign exchange for Mexico, accounting for earnings of US\$196 million-over 20 percent of Mexico's total foreign exchange earnings. ${ }^{ \pm 6}$ In addition, taxes on cotton exports brought in about US $\$ 15$ million per year. ${ }^{47}$ About 70 percent of cotton exports went to Japan, Mexico's most important trade partner after the United States. The balance of trade between the two countries ran strongly in Mexico's favor. In 1962, for example, while Mexico's exports to Japan were valued at US\$127.8 million, Mexico's imports from Japan totaled only US $\$ 22.6$ million. For a number of years, the Japanese Government had been pressuring Mexico to increase its imports; it even offered a loan of US\$roo million if there were some improvement in this regard. ${ }^{48}$ The Japanese Government was therefore able to use its position as Mexico's major cotton buyer as a lever: it threatened to cut cotton imports if Nissan's application were not approved. The threat worked.

Because of its historical commitment to the national bourgeoisie, the Mexican state's capitulation in approving some wholly foreign-owned firms weakened its ability -and perhaps its resolve-to turn down applications by some firms that were wholly or majority Mexican-owned. State-owned Diesel Nacional (DINA) had been assured of a place in

45 An application from a wholly Mexican-owned venture to manufacture Datsuns had been turned down during the normal period of application, though the approval of Reo allowed the manufacture of one Japanese make (Toyota). Since Reo failed during the first year, however, no Japanese makes were initially included in the Mexican market.

${ }^{46}$ Lic. Raúl Salinas Lozano, Memoria de Labores, 1963 (Mexico, D.F.: Secretaria de Industria y Comercio 1963), I36-37.

${ }^{47}$ Comercio Exterior, May I96I, p. 287.

${ }^{48}$ Comercio Exterior, March i963, p. I67. 
the industry from the beginning. Vehículos Automotores Mexicanos (VAM) was a well-established venture of Sociedad Mexicana de Crédito Industrial, one of the country's largest industrial development banks. Fábricas Auto-Mex's hand was strengthened by its being majority-owned by a wealthy and well-connected Mexican family. In the cases of Impulsora Mexicana Automotriz, Reo, and Representaciones Delta (all private firms, roo percent Mexican-owned), political favoritism and perhaps bribes rather than technical competence or financial clout were responsible for their being approved when other domestically owned ventures were rejected.

In all, ten firms were approved to manufacture in Mexico, far more than the NAFIN Report had recommended and far more than the size of the Mexican market warranted. When the government realized that it would not prevail in limiting the number of firms, it pinned its hopes on competition to winnow the industry down over the next few years. To some extent, that was a vain hope: the NAFIN Report had correctly predicted that competition would not drive out subsidiaries of the transnational firms, because of the ability of these firms to crosssubsidize their various international operations. Also, steps were taken to protect the national firms (both public and private) from the size and superior resources of the foreign firms. A system of production quotas limited the output of all firms and thus ensured a share of the market for the Mexican firms-thereby further reducing the possibility of elimination through competition.

On some issues, the Mexican Government did succeed in accomplishing its goals. The firms that had been approved would be required to manufacture 6o percent of each vehicle in Mexico. Further, these firms would be limited to the machining of the motor and the final assembly of vehicles. Other manufacturing activities would be reserved for a supplier industry that needed to be created-and the burden would fall squarely on the transnational firms in the terminal industry to assist in this development. ${ }^{49}$

The opposition of the American firms and their allies proved sufficient to have removed from the auto decree the other key requirements concerning product differentiation-freezing of models, standardization of parts, and limits on the number of acceptable makes and models. The question of the exclusion of these firms had been a particularly sharp issue in the bargaining, and when they prevailed on

${ }^{49}$ In later bargaining, some of the terminal firms secured approval for more vertical integration. A number of firms now have approval to cast their own engine blocks, Volkswagen is permitted to make its own body stampings, and so forth. 
this, they won as well the right to manufacture automobiles in their accustomed manner-with product differentiation and annual model changes.

Organizational constraints on the exercise of state power. The government's proposals for rationalizing the auto industry had been undermined on certain fundamental issues-the number of firms, the ownership of the terminal industry, product differentiation. In view of the potential power of the state, it is important to ask why the state's trump card-the pattern of oligopolistic competition in the automobile industry-was largely un- or under-played.

At first glance, there is a simple and plausible answer: certain characteristics of the structure of dependence-particularly political and economic relations with the United States and Japan-allowed the TNCs to muster the support of their home governments and change the game to one in which Mexico's card was no longer trump. But it is possible that the Mexican state could have acted differently. There were alternative strategies (recognized by at least some high officials at the time) that it might have pursued to take better advantage of its potential power.

In the case of the U.S. firms, a divide-and-rule strategy could have been tried, playing one of them against the other two. Alternatively, the government could have yielded on the question of limiting the number of firms, but insisted that these firms submit to much stiffer regulations on firm behavior, such as limits on product differentiation and on ownership. In the case of Nissan, the state might have responded to the Japanese Government's pressure by negotiating for the entrance of substantial Japanese investment in some other industrial structure, or even by calling its bluff: as some Mexican officials were aware (particularly in the Finance Ministry), Japan could not easily have found suitable alternatives for the long-fibered Mexican cotton needed for its textile industry.

The point is not that these strategies would necessarily have succeeded, but rather that the Mexican state had potential power and alternative courses of action that it did not employ. Why not?

When an actor in a power conflict is a collectivity rather than a single person, there may be organizational constraints on the utilization of potential power. For internal reasons, the actor may not be able to draw on all of the potential power that is theoretically available to it. With a complex entity like the state, such internal constraints may stem from a lack of the organizational coordination that is necessary 
to wield its potential power to full effectiveness. In the case at hand, we must examine the relations among specific agencies and departments and the bureaucratic politics of policy formation inside the Mexican Government. ${ }^{50}$ We will confine ourselves to three aspects of internal lack of unity.

I. Not only did the two ministries that were centrally concerned with industrial policy (the very powerful Finance Ministry and the Ministry of Industry and Commerce), fail to coordinate their automobile policy; they were seriously at odds during much of the planning period. Prior to the López Mateos Administration, the Finance Ministry had controlled the two principal policy instruments for industrial planning-tax policy and import tariffs and quotas. Such steps as were taken to encourage greater local content in the automobile industry were the work of the Finance Ministry's capable Department of Financial Studies. When the Ministry of Industry and Commerce was reorganized in 1959, it was given control (among other measures to strengthen it) over import tariffs and quotas; questions of automobile policy became principally its concern. The Finance Ministry resisted the diminution of its control over import policy, however, and the conflict between the two ministries became quite sharp, at times requiring presidential mediation. The Director of the Department of Financial Studies (who had been in his post a number of years, and had considerable experience with the automobile industry) supported a much stronger automobile policy along the lines of the original NAFIN Report. Had there been effective coordination between these two ministries, Industry and Commerce would have had powerful support for taking a tougher line. However, Industry and Commerce proceeded alone, using import controls as its only tool. (Tax policy toward the industry was not negotiated until after the I962 Decree, and the Finance Ministry flatly refused to grant the firms any fiscal incentives.) The making and implementing of automobile policy became a means by which Industry and Commerce established a sphere of autonomy, but the cost was a diminution of the state's effective power. ${ }^{51}$

${ }^{50} \mathrm{Cf}$. the discussion of divisions within the Mexican state as weakening its bargaining position vis-à-vis foreign drug companies, in Gereffi (fn. 3), 279-84. Organizational constraints within the TNCs themselves, while beyond the scope of this paper, are also important to a full analysis of the transformation of potential into actual power. See Gereffi, ibid. For a broad general discussion, see also Alfred D. Chandler, Jr., Strategy and Structure: Chapters in the History of the American Industrial Enterprise (Cambridge: M.I.T. Press I962).

${ }^{51}$ Parallel to this lack of coordination was the failure of Industry and Commerce to make use of the state's own automobile firm, Diesel Nacional, nominal control over 
2. There were also serious divisions inside the Ministry of Industry and Commerce. The Director and Sub-Director of Industries had been deeply involved in the technical studies that preceded the bargaining. Like their counterparts in the Department of Financial Studies with whom they had developed close informal relationships (the antagonism was chiefly at the Ministerial level), they believed that a much stronger policy could be successfully carried forward. Their superiors, however, the Secretary and the Assistant Secretary, felt that moderation, and compromise with the companies, was necessary. It is difficult to know for certain why these top officials were reluctant to take a tougher position, but interviews with officials in and out of the Ministry indicate that there were several factors. For one, there was a difference of goals. While there was broad agreement in the Ministry that limiting the number of firms was important, these top officials also placed a high priority on diversification of the sources of foreign investment; hence, they were inclined to look favorably on the applications of, for example, Promexa (Volkswagen) and Nissan.

Moreover, the political situation of the Secretary and Assistant Secretary made it somewhat difficult for them to assume a tougher position in the face of corporate pressure. In the Mexican political system, the change of President every six years brings with it changes in all major policy-making posts. Although a person is unlikely to retain the same position, many move to new positions of importance. ${ }^{52}$ Cabinet Secretaries are typically the strongest candidates for selection as the next President. Among other factors, a politician's future will depend on the immediate political consequences of his decisions in the previous sexennium - the friends and enemies he has made, the controversies in which he has been involved. Thus, the incentive to pursue risk-minimizing strategies and to judge policies narrowly in terms of their short-run political consequences is strong. Since the deleterious effects of admitting too many firms to the industry would not be felt immediately, only an unusual person would have risked a full-scale confrontation with Ford, General Motors and the U.S. Government, or with the Japanese Government-unless he had the support of the President.

which lay with yet a third ministry, National Properties. DINA could have been a valuable source of technical and financial information about automobile manufacturing; it could have been allotted a place in the industry which would have made it a tool of industrial policy (a competitive check on the other firms). DINA's earlier troubles, however, hardly inspired confidence.

52 Peter Smith, "Does Mexico Have a Power Elite?" in Richard S. Weinert and José Luis Reyna, eds., Authoritarianism in Mexico (Philadelphia: ISHI Publications 1977). 
Finally, there was a close connection between the Ford Company and the Ministry of Industry and Commerce. It was not simply a personal relationship between the manager of Ford de México and the Minister: from the very beginning of the López Mateos Administration, Ford had openly supported the Ministry's goal of moving toward the manufacturing of automobiles. In 1960, following a strategy he had recently employed in Argentina, Ford's manager put his staff to work on a lengthy feasibility report and an accompanying proposal of what Ford itself would be willing to do in Mexico. He reckonedquite rightly - that such early cooperation would give Ford an inside track on approval and policy input that would result in a policy that the company would find amenable. How much Ford's influence was responsible for the divisions within the Ministry of Industry and Commerce, and how much it was made possible by divisions already there, is difficult to determine.

3. Because of the centralization of power in the hands of a Mexican President, it is possible that his explicit direction and firm support could have forged the inter- and intra-Ministerial unity necessary to act more forcefully in putting forward a stronger automobile policy. Indeed, interviews show that a lack of direction left key officials on their own (and thus made it rational for them to pursue risk-minimizing strategies), and that specific directives to "ease up" on the transnational firms, and to give favorable consideration to applications from certain Mexican-owned firms, filtered down from the President himself at crucial points in the bargaining. In the context of the Mexican political system, only resolute guidance from the President could have fended off the pressures that were being brought to bear, and this guidance was not forthcoming.

\section{Conclusion}

The bargaining conflict between the Mexican state and the transnational automobile corporations between 1960 and 1964 was only the first round of what has proved to be an ongoing struggle. There have been a number of new negotiations, the most important of which took place in 1968-1969 and again in 1976-1977; but the initial round was the most decisive encounter because it set the terms for all subsequent bargaining.

Studies of bargaining power in natural resource industries have shown that the power of the state is lowest at the time of initial bargaining because of uncertainties about the amount, quality, and costs 
of extraction of the natural resources. Once the large initial investments have been made, however, the balance of power swings dramatically in favor of the state: the uncertainties are reduced and the fixed investments are "hostage" to the LDC. ${ }^{53}$

In a high-technology, consumer-goods manufacturing sector such as the automobile industry, the situation is often reversed. Access to the domestic market is the state's principal basis of bargaining power, and can be used most effectively at the point of initial investment. After that, the firms are entrenched in the host country through their relationships with suppliers, distributors, labor, and consumers. Because such manufacturing enterprises are integrated into the local economy to a far higher degree than resource extractors, they establish relationships within the host country which significantly enhance their bargaining power, both by reinforcing the host country's needs for their kind of production and products and by being able to mobilize domestic allies. And so long as the industry is dependent upon external sources of technology, the possibility of nationalization by the host country is not a credible threat.

Other things being equal, then, the balance of bargaining power in such a manufacturing industry may with time shift toward the transnational firms rather than toward the LDC. The first bargaining encounter between the Mexican state and the automobile TNCs was therefore of paramount importance: here, the structure of the industry was first laid down; the state never again had the power to restructure the industry, and each subsequent renegotiation of policy occurred within the bounds set down in the first bargaining encounter. Both the problems and the alternative possibilities are defined within this structure.

The theoretical approach taken in this paper could be employed in the analysis of these subsequent bargaining encounters in the Mexican automobile industry, as well as in the analysis of bargaining between TNCs and the governments of other less developed countries, and in other industries. We have been concerned with two central issues: agenda setting and bargaining power.

Agenda setting. Understanding the bargaining agenda requires a knowledge of the actors (or interests) that obtain access to the bargaining arena and of those that are excluded. The character of Mexico's political institutions explains not only the exclusion of labor from the

${ }^{53}$ On this argument, see Moran, Multinational Corporations and the Politics of Dependence (fn. 3), $157-62$. 
bargaining table, but also the promotion of certain interests of the national bourgeoisie by the Mexican state (despite the rather small role played by Mexican entrepreneurs in the bargaining). Once it is clear which actors and interests are to be included, the points of conflict and of convergence of interest among the major actors must be analyzed. It should not be supposed that the interests of TNCs and LDC governments conflict across the board: the points of convergence of interests simply do not become bargaining issues. In the case of Mexico after World War II, a strategy of import substitution laid the basis for substantial convergence of interests among the government and TNCs in a range of manufacturing industries. The convergence of interests in the automobile industry-given its worldwide dynamics of competition-went no further than assembly operations, however. The exercise of state power was necessary to induce the auto firms to commence domestic manufacture. The state's requirement for local content was not the most controversial proposal, however, because it merely propelled the firms further along a competitive trajectory on which they were already engaged worldwide. But other proposals-a strict limitation on the number of firms, ownership restrictions, and constraints on product differentiation-did become major points of conflict in the bargaining: they threatened the established competitive strategies of the firms in the industry (particularly of the U.S.-based firms, which were the most active in the bargaining because of their prior penetration of the market).

Bargaining power. The potential power available to each actor to setthe the contested issues cannot be understood as consisting simply of its possession of certain resources. Whether a resource can serve as a source of potential power depends on the context-particularly on the structure of domestic and international relationships in which each actor is enmeshed. Such relationships help in defining which resources can serve as bases of potential power. It was, for example, the relationship between the Mexican state and certain domestic classes that established Mexico's "need" for a domestic automobile industry and thus allowed the TNCs' control of automobile technology to serve as their power resource. Such relationships also determine when power resources can be employed or withheld, as demonstrated in the pattern of competitive relationships in the world's automobile oligopoly that made each of the firms eager to gain access to the Mexican market. Finally, such relationships define the potential for the entry of new actors into the conflict as allies-as shown by the firms' mobilization of domestic suppliers and distributors and of their home governments. 
Potential power must be carefully distinguished from actual power: an actor may have sources of power upon which it does not draw effectively. In this conflict, the TNCs drew more effectively upon their potential power than did the Mexican state. The potential power that accrued to the Mexican state from the pattern of oligopolistic competition in the world's automobile industry was an advantage which it did not utilize fully. In order to understand the reasons, we must realize that the host government is not a single unified entity. Conflicts within and especially between various agencies, and the lack of central direction from the President weakened the Mexican state's ability to draw fully upon its potential power. 